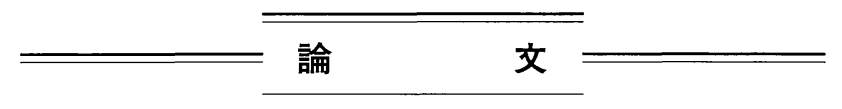

農業気象 (J. Agric. Meteorol.) 52 (2): 99-106, 1996

\title{
Analysis and Modeling of Dry Matter Production Rate by Soybean Community - Curvilinear Response to Radiation Intensity -
}

\author{
Ryoji SAmeshima \\ (Japan International Research Center for Agricultural Science
Ohwashi 1-2, Tsukuba, Ibaraki, 305 Japan
}

\begin{abstract}
The linear relationship between the amount of absorbed radiation and dry matter production by crop communities has long been known, and the proportionality constant between them is known as the radiation use efficiency $(R U E)$. To analyze and predict crop production using $R U E$, the assumption is often made that $R U E$ is not sensitive to radiation intensity and that dry matter production rate $(D M P R)$ is a linear function of radiation intensity.

However, there is evidence in opposition to this assumption, including reports of increasing $R U E$ in shade tests, and hyperbolic response of photosynthetic rate to radiation intensity. The following model was developed and used to analyze the response of DMPR and RUE to daily radiation $R_{S}$ :$$
D M P R=D M P R_{\max }\left(R_{S}\right) * g(\alpha)
$$

where $D M P R_{\max }\left(R_{S}\right)$ is the $D M P R$ of a hypothetical soybean community absorbing all radiation, and $g(\alpha)$ represents the effect of radiation absorptivity $(\alpha)$. A hyperbolic curve and a straight line were employed for $D M P R_{\max }\left(R_{\mathrm{S}}\right)$ and $g(\alpha)$, respectively. Field experimental data including shade tests were used to determine the parameters for the modet. Two sets of parameters were required to cover the entire experimental period. $D M P R_{\max }\left(R_{S}\right)$ had an apparent curvilinear relationship with $R_{S}$. The model successfully described dry matter production under successive low radiation conditions, which could not be estimated by a model with $R U E$ insensitive to radiation.
\end{abstract}

Key words: RUE, CGR, Growth analysis, Canopy photosynthesis, Glycine max (L.) Merr.

\section{Introduction}

The linear relationship between the amount of absorbed or intercepted radiation and dry matter production by crop communities has long been known (e.g. Shibles and Weber, 1966; Monteith, 1977), and the proportional constant is known as the radiation use efficiency $\left(R U E, \mathrm{~g} \cdot \mathrm{MJ}^{-1}\right) \cdot R U E$ is a convenient parameter for estimating crop dry matter production $\left(D M P, \mathrm{~g} \cdot \mathrm{m}^{-2}\right)$, and has often been successfully used in crop growth models.

Presented at the Annual General Meeting on July 25, 1989. Received on August 7, 1995.

Accepted on January 31, 1996.

Present address: Tohoku National Agricultural Experiment Station, Morioka, Iwate, 020-01 Japan.
These models typically assume that RUE is not sensitive to radiation intensity. That is, the dry matter production rate $\left(D M P R, \mathrm{~g} \cdot \mathrm{m}^{-2} \cdot \mathrm{day}^{-1}\right)$ responds linearly to radiation intensity which has often been represented by the amount of daily radiation $\left(R_{S}, \mathrm{MJ} \cdot \mathrm{m}^{-2} \cdot \mathrm{day}^{-1}\right)$. This type of model will be referred to as the $R_{S}$-linear model in this report.

There are, however, some reports that do not support the $R_{S}$-linear model. Murata (1981), Nakaseko and Gotoh (1983), and Horie and Sakuratani (1985) observed that RUE changed depending on $R_{S}$. Sinclair et al. (1992) showed theoretically that $R U E$ decreased with the increase in $R_{S}$. Murata and Iyama (1961), Kumura (1965, 
1968), Sakamoto and Shaw (1967), and Ingram et al. (1981) observed that the photosynthetic rate of a soybean community responded curvilinearly to radiation intensity. These studies suggest that there is non-linear relationship between $D M P R$ and $R_{S}$, and the $R_{S}$-linear model does not necessarily describe the real relationship between $D M P R$ and $R_{S}$ over the entire range of $R_{S}$. Applying the $R_{S}$-linear model to such studies as analysis or prediction of damaged crop growth caused by low solar radiation, therefore, may lead to errors in estimation.

The purposes of this study are to develop a simple model that relates $D M P R$ to $R_{S}$ with a curvilinear relationship, and to examine the response of DMPR and RUE to $R_{S}$. Soybean (Glycine max Merr. cv. Enrei) was used for the study.

\section{Materials and methods}

\subsection{Modeling}

$D M P R$ was modeled by the following equation, which is referred to as the $R_{S}$-nonlinear model in this report:

$$
D M P R=D M P R_{\max }\left(R_{S}\right) \cdot g(\alpha)
$$

where $D M P R_{\max }$ is the $D M P R$ of an ideal canopy with radiation absorbtivity $(\alpha)$ of 1.0. $g(\alpha)$ represents the effect of $\alpha$ on DMPR. Appropriate functions for $D M P R_{\max }\left(R_{S}\right)$ and $g(\alpha)$ were chosen based on results found in the literature. Absorbtivity was calculated by the method of sameshima (1995).

The parameters of the model were determined by the following procedure. The square sum of differences $\left(e^{2}\right)$ between the actual and calculated $D M P$ obtained by the model was calculated as follows:

$$
e^{2}=\sum_{i=1}^{10} \sum_{j=1}^{N i}\left(\text { Actual } D M P_{i, j}-\text { Calculated } D M P_{i, j}\right)^{2}
$$

where $i$ indicates plot number (Table 1 ) and $N_{i}$ is the number of samples for of the $i$ th plot. A parameter set yielding minimum $e^{2}$ was determined by the Simplex method with the computer program developed by Kobayashi (1981). In this procedure, $\alpha$ was calculated using actual $L A I$. Solar radiation data $\left(R_{S}\right)$ from the observatory of the National Institute of Agro-Environmental Sciences (NIAES, about $300 \mathrm{~m}$ apart from the experimental field) were used.

In this study RUE was estimated on a daily time scale using total above-ground dry matter and absorbed radiation (see Arkebauer et al., 1994).

\subsection{Field experiment}

Soybean (Glycine max Merr. cv. Enrei) was grown in 1987 and 1988 at the experimental field of the National Agriculture Research Center (lat. $36^{\circ} 01^{\prime} \mathrm{N}$, long. $140^{\circ} 07^{\prime} \mathrm{E}, 25 \mathrm{~m}$ above sea level, black volcanic ash soil). In each year, soybean was seeded on the days shown in Table 1. Plant spacing, row spacing and planting density were $0.2 \mathrm{~m}$, $0.6 \mathrm{~m}$ and $8.3 \mathrm{plant} \cdot \mathrm{m}^{-2}$, respectively. $30 \mathrm{~kg} \cdot \mathrm{ha}^{-{ }^{\prime}}$ of nitrogen, $100 \mathrm{~kg} \cdot \mathrm{ha}^{-1}$ of phosphoric acid and $100 \mathrm{~kg} \cdot \mathrm{ha}^{-1}$ of potassium were applied before seeding in all the plots. The soybeans were chemically protected against pests and diseases throughout the growth period.

In three plots, shading treatments were conducted by spreading nets of cheese cloth over the plots at the height of $1.2 \mathrm{~m}$. At every side of these plots, the net was hung down $0.5 \mathrm{~m}$ from the top. The shading treatments were carried out starting on August 7, 1987 and Jun 30, 1988. Soybeans of $1988 b_{\text {sh }}$ grew spindly and could not stand

Table 1 Names, dates of seeding, flowering, and maturity, shading

\begin{tabular}{|c|c|c|c|c|c|c|}
\hline No. & plot name & seeding & flowering & maturity & shade ratio & plot size $(\mathrm{m})$ \\
\hline 1 & $1987 a$ & Jun 30 & Aug. 7 & Oct. 5 & - & $10 \times 20$ \\
\hline 2 & $1987 a_{s}$ & Jun 30 & Aug. 6 & Oct. 5 & 0.48 & $5 \times 20$ \\
\hline 3 & $1988 \mathrm{a}$ & May 10 & Jul. 12 & Oct. 5 & - & $10 \times 20$ \\
\hline 4 & $1988 b$ & Jun 10 & Jul. 31 & Oct. 6 & - & $10 \times 20$ \\
\hline 5 & $1988 b_{s l}$ & Jun 10 & Jul. 30 & Oct. 6 & 0.48 & $5 \times 20$ \\
\hline 6 & $1988 b_{\text {sh }}$ & Jun 10 & Jul. 30 & Oct. 1 & 0.78 & $5 \times 20$ \\
\hline 7 & $1988 \mathrm{c}$ & Jul. 11 & Aug. 21 & Oct. 17 & - & $10 \times 20$ \\
\hline 8 & $1988 d$ & Aug. 4 & Sep. 6 & Oct. 31 & - & $10 \times 20$ \\
\hline 9 & $1988 \mathrm{e}$ & Aug. 24 & Sep. 26 & - & - & $10 \times 20$ \\
\hline 10 & $1988 f$ & Sep. 8 & Oct. 28 & - & - & $10 \times 20$ \\
\hline
\end{tabular}
ratio, and size of each experimental plot. 
straight, and glass fiber poles with a diameter of $0.005 \mathrm{~m}$ were used to support them.

In each plot, five plants that showed average growth were sampled two or three times a week, then the median of the five was chosen for leaf area measurement $\left(\mathrm{m}^{2}\right)$ with a leaf area meter (Hayashi Inc., AAC-400). The sampled plant was placed in a dryer at $80^{\circ} \mathrm{C}$ for 72 hours and the total dry weight of the part above the primary leaf node was measured. Leaf area index $(L A I)$ and $D M P$ were determined by multiplying the leaf area and the dry weight of a plant by the planting density. These samplings and measurements were conducted from emergence until the leaves became yellow and began to fall in each plot.

To compare the inside and outside conditions of the shaded plot, solar radiation was measured in $1987 \mathrm{a}, 1987 \mathrm{a}_{\mathrm{s}}, 1988 \mathrm{~b}, 1988 \mathrm{~b}_{\mathrm{sl}}, 1988 \mathrm{~b}_{\mathrm{sh}}$ at $1.0 \mathrm{~m}$ above the ground with solarimeters (Eiko Inc. MS42) using a data logger (Eiko Inc. SOLAC-III) connected to with a PC (NEC Inc. PC98-LT). Shading ratio was expressed as $\{1-$ (daily radiation inside the shaded plot)/(daily radiation outside the shaded plot)\}.

\section{Results and Discussion}

\subsection{Modeling}

The simplest function for $D M P R_{\max }\left(R_{S}\right)$ and $g(\alpha)$ in equation (1) is:

$$
\begin{aligned}
& D M P R_{\max }\left(R_{S}\right)=R U E \cdot R_{S} \\
& g(\alpha)=\alpha
\end{aligned}
$$

Substituting equations (2a) and (2b) into (1) with a constant value of $R U E$ gives the $R_{S}$-linear model. Therefore, the $R_{S}$-linear model is regarded as a specific case of the $R_{S}$-nonlinear model.

As reported in the introduction, it has been observed that the photosynthetic rate of soybean communities has a hyperbolic response to radiation intensity. Although these results in the literature were obtained from $\mathrm{CO}_{2}$ exchange rates on a time-scale of an hour or shorter, they suggest that $D M P R$ has a hyperbolic relationship with $R_{S}$. Saeki (1960) calculated that daily photosynthesis of a cockscomb (Celosia cristata) community responded hyperbolically to $R_{S}$. The use of the following function, therefore, should be reasonable:

$$
D M P R_{\max }\left(R_{S}\right)=\left\{a \cdot\left(R_{S}-c\right)\right\} /\left\{b+\left(R_{S}-c\right)\right\}
$$

where $a, b$ and $c$ are parameters. $c$ represents the light compensation point and was ignored in this study because it is quite small (Kumura, 1965).

Pearce et al. (1967) and Wells (1991) observed that the canopy photosynthesis increased in proportion to the fraction of intercepted radiation by the canopy $(\tau)$. Sameshima (1995) showed that $\tau$ is linearly related to $\alpha$. These results indicate that $g(\alpha)$ is linear. It is also apparent from the definition of the $R_{S}$-nonlinear model that $g(\alpha)_{\alpha=1}$ $=1$ and $g(\alpha)_{\alpha=0}=0$. Equation (2b), therefore, is applicable also to the $R_{S}$-nonlinear model.

\subsection{Overview of the experimental data by the conventional method}

First, the field experimental data were studied by the conventional plotting method, which will be referred to as a $R_{\text {absorbed }}-D M P$ chart in this report.

Fig. 1 shows air temperature and rain fall at the NIAES observatory in 1988 and the period from seeding to the end of sampling in each plot.

The relationship between accumulated absorbed radiation $\left(R_{\text {absorbed }}, \mathrm{MJ} \cdot \mathrm{m}^{-2}\right)$ and $D M P$ for the experiments of 1988 is shown in Fig. 2. The slope of the regression line is the RUE. As shown in Fig. 2 , the $R U E$ in the five plots was nearly the same, and the averaged value was $1.36\left(\mathrm{~g} \cdot \mathrm{MJ}^{-1}\right)$.

Air temperature in the experiments was between $14^{\circ} \mathrm{C}$ and $26^{\circ} \mathrm{C}$ (Fig. 1). Fukui et al. (1965) and Murata and Iyama (1961) observed that soybean

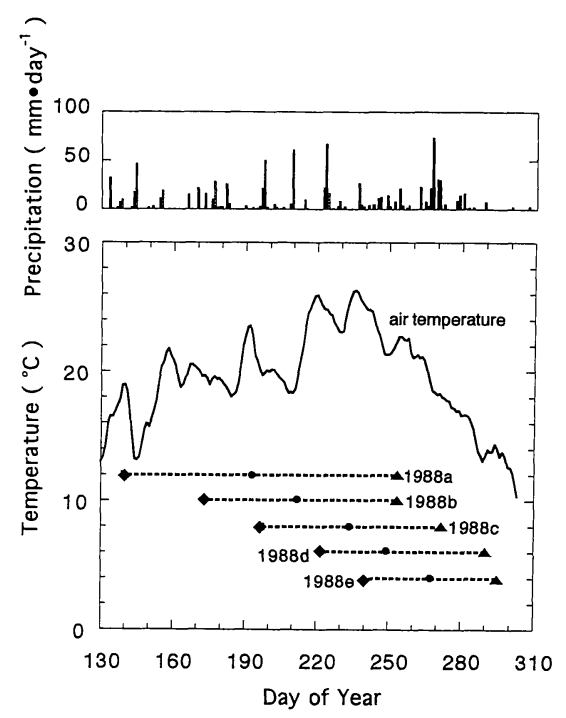

Fig. 1. Air temperature and precipitation in 1988. , $\boldsymbol{\Delta} \Delta$ indicate seeding, flowering, and end of the sampling of each plot, respectively. Change in five-day average temperatures is illustrated. 

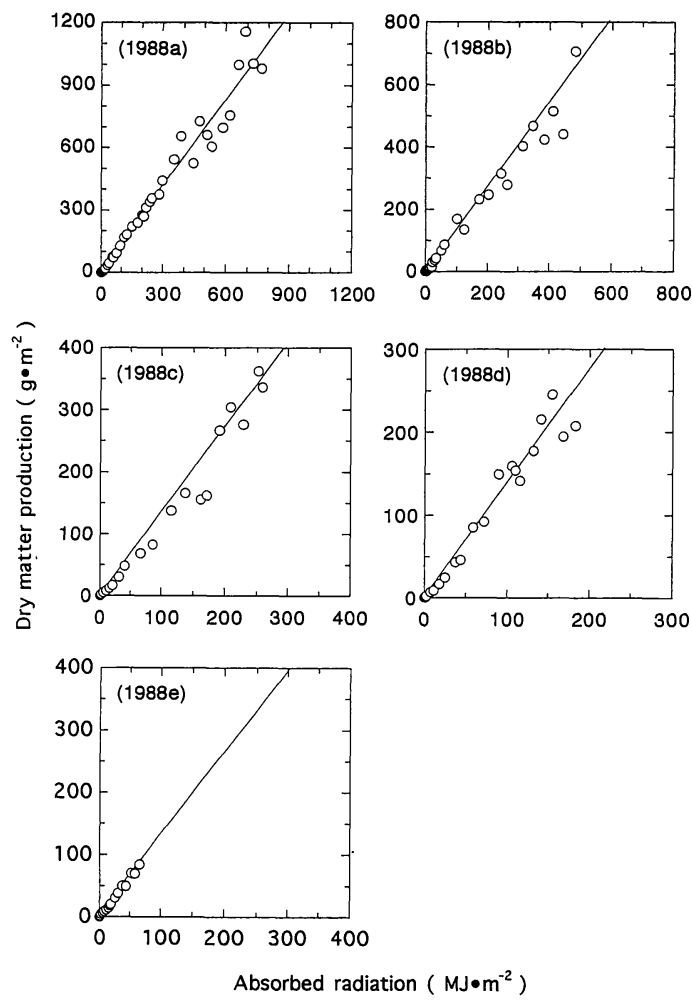

Fig. 2. $R_{\text {absorbed }}-D M P$ charts.

Line in each plot indicates $R U E=1.36\left(\mathrm{~g} \cdot \mathrm{MJ}^{-1}\right)$.

photosynthesis had little response to temperature in the temperature range from $15^{\circ} \mathrm{C}$ to $30^{\circ} \mathrm{C}$, and from $25^{\circ} \mathrm{C}$ to $35^{\circ} \mathrm{C}$, respectively. Muchow et al. (1993) reported that $R U E$ was not sensitive to temperature. Although discussing temperature effect is beyond the scope of this study, it can be assumed that air temperature had little effect on $D M P R$ and $R U E$ in this experiment.

The $R_{\text {absorbed }}-D M P$ charts shown in Fig. 3 use the same data as those in Fig. 2, but focus on the early growth period. $R U E$ in this period was apparently smaller than the averaged value over the whole period $\left(=1.36 \mathrm{~g} \cdot \mathrm{MJ}^{-1}\right)$. Nakaseko and Gotoh (1981), and Shiraiwa and Hashikawa (1993) also reported that $R U E$ changed depending on the growth stage (they used other terminology instead of $R U E)$.

In Fig. 4, data of the five plots in 1988 were combined. In the range where $D M P$ was less than $20 \mathrm{~g} \cdot \mathrm{m}^{-2}\left(2.4 \mathrm{~g} \cdot\right.$ plant $\left.^{-1}\right)$, marked by the broken lines in the figure, $R U E$ was low. In this range, $R U E$ was $0.88\left(\mathrm{~g} \cdot \mathrm{MJ}^{-1}\right)$. In Fig. 4, calculated $D M P$ with $R U E$ of $0.88\left(\mathrm{~g} \cdot \mathrm{MJ}^{-1}\right.$, when $D M P<$
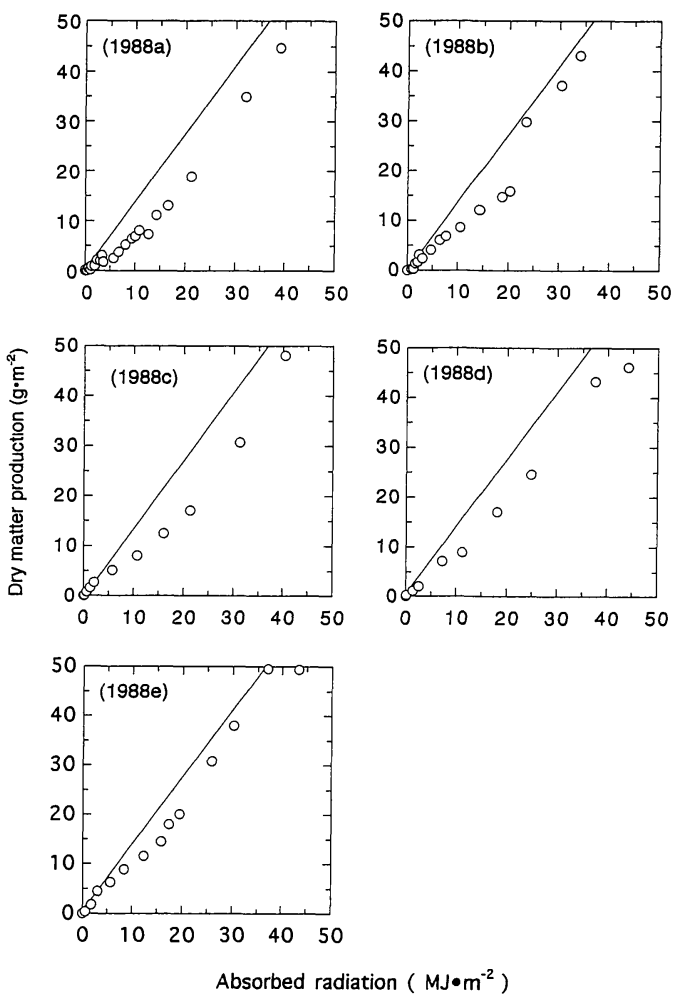

Fig. 3. $R_{\text {absorbed }}-D M P$ charts.

Line in each plot indicates $R U E=1.36\left(\mathrm{~g} \cdot \mathrm{MJ}^{-1}\right)$.

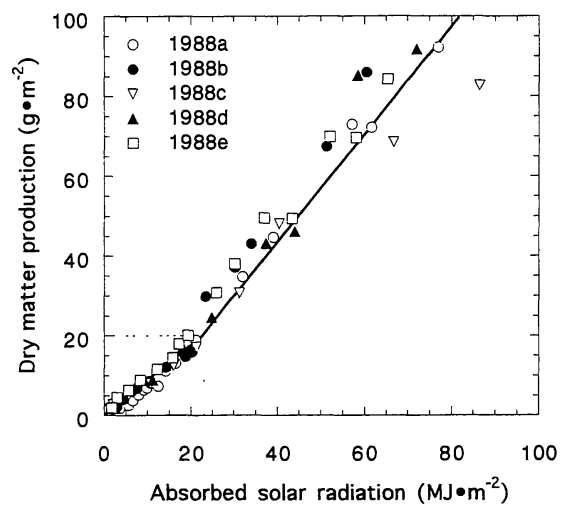

Fig. 4. $R_{\text {absorbed }}-D M P$ chart. - calculated $D M P$.

$\left.20 \mathrm{~g} \cdot \mathrm{m}^{-2}\right)$ and $1.36\left(\mathrm{~g} \cdot \mathrm{MJ}^{-1}\right.$, when $D M P \geq 20 \mathrm{~g}$. $\left.\mathrm{m}^{-2}\right)$ is illustrated.

Changes in dry matter and $L A I$ of the three plots $\left(1988 \mathrm{~b}, 1988 \mathrm{~b}_{\mathrm{sl}}, 1988 \mathrm{~b}_{\mathrm{sh}}\right.$, each of which was seeded in the same day) are shown in Fig. 5. Decreases in dry matter and $L A I$ caused by the shading treatments were particularly large in $1988 b_{\text {sh }}$. Fig. 6 is the $R_{\text {absorbed }}-D M P$ chart for 

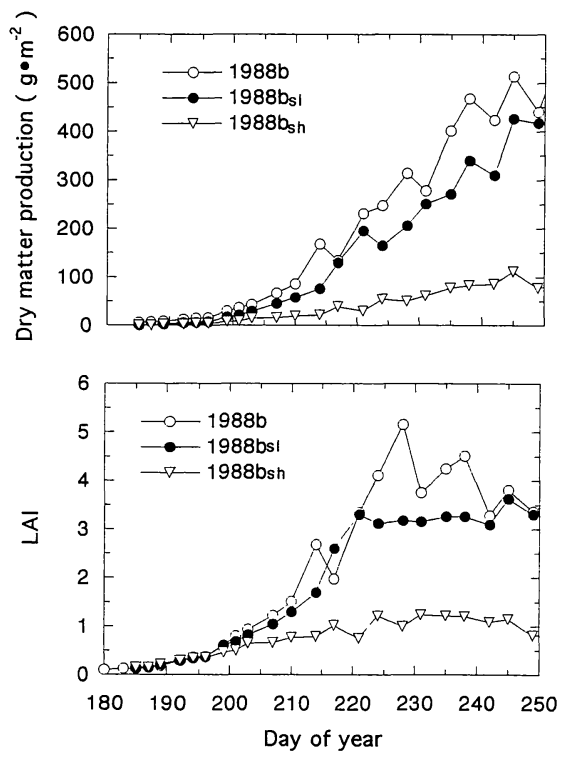

Fig. 5. Changes in dry matter, $L A I$ and $S L A$ of $1988 \mathrm{~b}, 1988 \mathrm{~b}_{\mathrm{sl}}, 1988 \mathrm{~b}_{\mathrm{sh}}$.

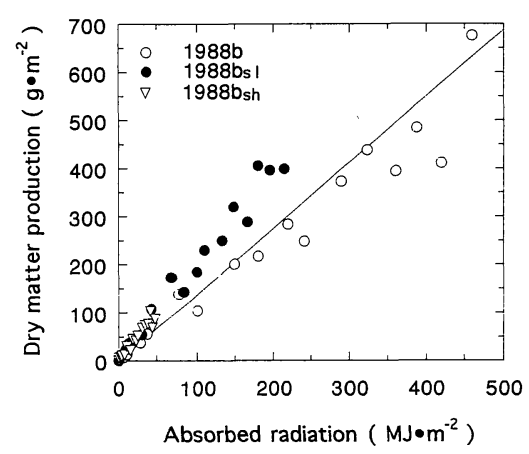

Fig. 6. $R_{\text {absorbed }}-D M P$ chart for $1988 \mathrm{~b}, 1988 \mathrm{~b}_{\mathrm{s} 1}$, $1988 b_{\text {sh }}$.

$1988 \mathrm{~b}, 1988 \mathrm{~b}_{\mathrm{sl}}$ and $1988 \mathrm{~b}_{\mathrm{sh}}$. RUE apparently increased in the shading treatments.

\section{3 $R_{S}$-nonlinear model}

Parameters for the $R_{S}$-nonlinear model, expressed by equation (2b) and (3), were derived from all the data for all plots, and the parameter set $\mathrm{p} 1$ given in Table 2 was obtained. Actual and calculated dry matter by $R_{S}$-nonlinear model with P1 is shown in Fig. 7 (a) for 1988b. It appears that the model estimated dry matter production successfully. Calculated dry matter in the early growth period, however, is overestimated as shown in Fig. 7 (b). This error was anticipated from the fact that $R U E$ in the early growth period was lower than the rest of the growth period as noted above.
Table 2 Parameters for the $R_{S}$-nonlinear model.

\begin{tabular}{|c|c|c|c|}
\hline Name & a & $\mathrm{b}$ & used data \\
\hline $\mathrm{P} 1$ & 63.2 & 29.6 & whole experimental period \\
\hline \multirow{2}{*}{ P2 } & 30.3 & 30.0 & dry matter $\leq 2.4\left(\mathrm{~g} \cdot\right.$ plant $\left.^{-1}\right)$ \\
\hline & 40.6 & 12.9 & dry matter $>2.4\left(\mathrm{~g} \cdot\right.$ plant $\left.^{-1}\right)$ \\
\hline
\end{tabular}

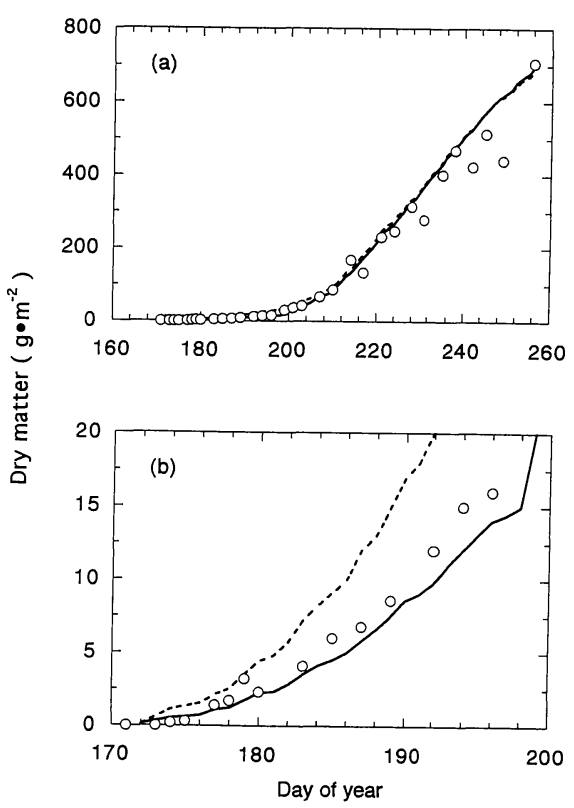

Fig. 7. Actual and calculated dry matter. $O$ : actual

- . . . . : : calculated with the parameter set P1

- : calculated with the parameter set P2

(b) is the enlarged figure of the early growth period of (a).

To overcome this error, the whole growth period was divided into two parts and a parameter set for each period was obtained. The obtained parameter set (P2) is given in Table 2. Dry matter pdoduction calculated with $\mathrm{P} 2$ agreed better than that with P1 as shown in Fig. 7 (b).

Although equation (3) can express a straight line with the proper parameters, $D M P R_{\max }$ curvilinearly responded to $R_{S}$ as illustrated in Fig. 8 (a). Fig. 8 (b) illustrates the dependence of $R U E$ on $R_{S}$ that is obtained by combining equation (2a) and (3). RUE decreases with an increase of $R_{S}$. Nakaseko and Gotoh (1983) and Sinclair et al. (1992) reported similar results. In addition to the direct effect of radiation intensity, the proportion of diffuse radiation possibly had some effect on $D M P R_{\max }$ and $R U E$. Kumura (1968) reported that photosynthetic rate was larger when there 
was a higher proportion of diffuse radiation even if the radiation intensity was the same.

$D M P R_{\max }$ has a non-linear relationship to $R_{S}$ as shown in Fig. 8 (a), but DMP under normal weather conditions was successfully estimated with the $R_{S}$-linear model, except for the initial growth period. Calculated $D M P$ by the $R_{S}$-linear model with $R U E=1.36$ was the same as the solid line in Fig. 7 (a). This indicates that $D M P$ can be estimated well by the mean $R U E$ corresponding to the mean $R_{S}$ over the entire growth period under normal weather conditions. The $R_{S}$-linear model, however, can not be applied to conditions
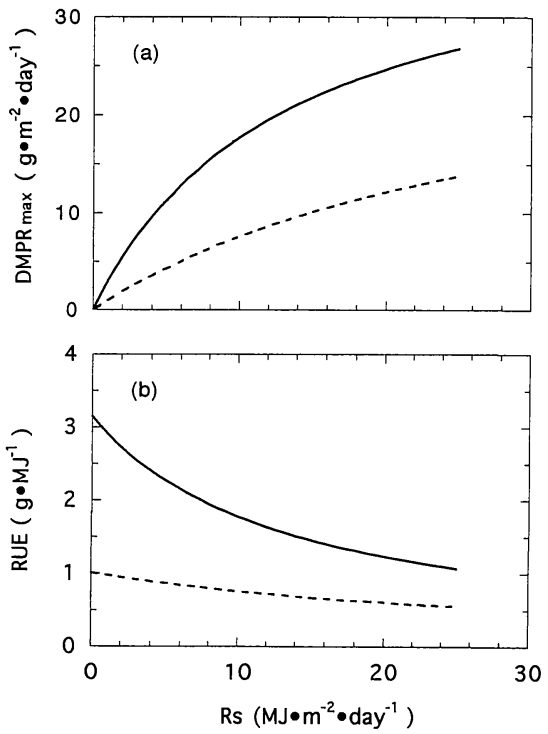

Fig. 8. Dependence of $D M P R_{\max }$ and $R U E$ on $R_{S}$ calculated with the parameter set $\mathrm{P} 2$.

-....: when dry matter is less than 2.4 (g plant $^{-1}$ )

when dry matter is larger than 2.4 ( $\mathrm{g}$. plant ${ }^{-1}$ )

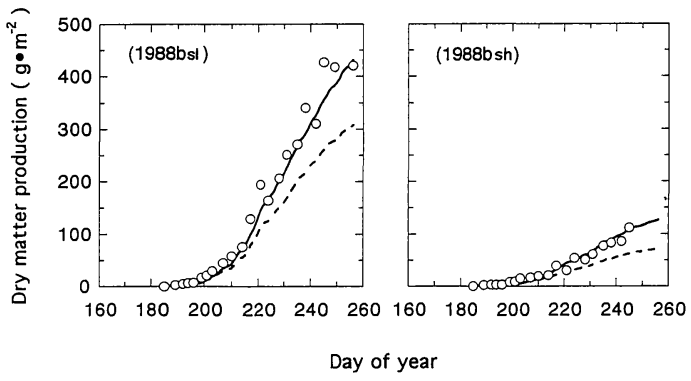

Fig. 9. Actual and calculated dry matter production of the shaded plots.

- by the $R_{S}$-nonlinear model with P2

- . . . . : : by the $R_{S}$-linear model with $R U E=1.36$ such as an extended period of low radiation as ahown in Fig. 9. The calculation made using the $R_{S}$-linear model underestimates the dry matter production under low radiation intensity. On the other hand, the $R_{S}$-nonlinear model can estimate dry matter production even in such an extremely low radiation intensity as the $78 \%$ shaded plot $\left(1988 b_{\text {sh }}\right)$.

In this study, the response of $D M P R_{\max }$ to $R_{S}$ was set to change suddenly when the dry matter of a plant reached $2.4 \mathrm{~g}$. This was determined empirically based on the data given in Fig. 4. Shiraiwa and Hashikawa (1993) also reported that $R U E$ was low in early growth period using cv. Enrei, however, the time of the change was later than that in this report. During the rest of the growth period, the response of $R U E$ to $R_{S}$ did not change in this study. However, Shiraiwa and Hashikawa (1993) and Muchow et al. (1993) reported that $R U E$ decreased during the seed filling period. These changes of $R U E$ are attributable to the decrease in the leaf nitrogen content (Ojima, 1965; Lugg and Sinclair, 1981; Sinclair and Horie, 1989) due to the translocation of nitrogen from vegetative to reproductive organs (Sinclair and de Wit, 1975). For more detailed description of $R U E$, therefore, $R U E$ should be modeled in connection with leaf nitrogen content as in the model developed by Sinclair (1986).

\section{Acknowledgment}

The author wishes to express his gratitude to Dr. Satoshi Iwakiri and Masao Nakajima for their encouragement and suggestions.

\section{References}

Arkebauer, T. J., Weiss, A., Sinclair, T. R. and Blum, A., 1994: In defense of radiation use efficiency: a response to Demetriades-Shah et al. (1992). Agric. For. Meteorol., 68, 221-227.

Fukui, J., Ojima, M. and Watanabe, I., 1965: Studies on the seed production of soybean. Jpn. J. Crop Sci., 33, 432-436.

Horie, T. and Sakuratani, T., 1985: Studies on crop-weather relationship model in rice (1) Relation between absorbed solar radiation by the crop and the dry matter production. $J$. Agric. Meteorol., 40, 331-342.

Ingram, K. T., Herzog, D. C., Boote, K. J., Jones, J. W. and Barfield, C. S., 1981: Effects of defoliating pests on soybean canopy $\mathrm{CO}_{2}$ 
exchange and reproductive growth. Crop Sci., 21, 961-968.

Kobayashi, K., 1981: A subroutine for function minimization by the simplex method. Bull. Compu. Cen. Res. Agr. For. Fish., Ser. A., 17, 51-71.

Kumura, A., 1965: Studies on dry matter production in soybean plant. 2. Influence of light intensity on the photosynthesis of the population. Jpn. J. Crop Sci., 33, 473-481.

Kumura, A., 1968: Studies on dry matter production in soybean plant. 3. Photosynthetic rate of soybean plant population as affected by proportion of diffuse light. Jpn. J. Crop Sci., 33 473-481.

Lugg, D. G. and Sinclair, T. R., 1981: Seasonal changes in photosynthesis of field-grown soybean leaflets. II Relation to nitrogen content. Photosynthetica, 15, 138-144.

Monteith, J. L., 1977: Climate and the efficiency of crop production in Britain. Phil. Trans. $R$. Soc. Lond. B., 281, 277-294.

Múchow, R. C., Robertson, M. J. and Pengelly, B. C., 1993: Radiation use efficiency of soybean, mungbean and cowpea under different environmental conditions. Field Crops Res., 32, 1-16.

Murata, Y. and Iyama, J., 1961: Studies on photosynthesis in upland field crops. I. Diurnal changes in the photosynthesis of eight summer crops growing in the field. Jpn. J. Crop Sci., 29, 151-154.

Murata, Y., 1981: Dependence of potential productivity and efficiency for solar energy utilization on leaf photosynthetic capacity in crop species. Jpn. J. Crop Sci., 50, 223-232.

Nakaseko, K. and Gotoh, K., 1981: Comparative studies on dry matter production, plant type and productivity in soybean, azuki bean and kidney bean III. Dry matter production of soybean plant at various population densities. Jpn. J. Crop Sci., 50, 38-46.

Nakaseko, K. and Gotoh, K., 1983: Comparative studies on dry matter production, plant type and productivity in soybean, azuki bean and kidney bean VII. An analysis of the basis of radiation absorption and its efficiency for dry matter accumulation. Jpn. J. Crop Sci., 52, $49-58$.
Ojima, M., Fukui, J. and Watanabe, I., 1965: Studies on the seed production of soybean II. Effect of three major nutrient elements supply and leaf age on the photosynthetic activity and diurnal changes in photosynthesis of soybean under constant temperature and light intensity. Jpn. J. Crop Sci., 33, 437-442.

Pearce, R. B., Brown, R. H. and Blaser, R. E., 1967: Photosynthesis in plant communities as influenced by leaf angle. Crop Sci., 7, 321-324.

Saeki, T., 1960: Interrelationship.between leaf amount, light distribution and total photosynthesis in a plant community. Bot. Mag. Tokyo, 73, 55-63.

Sakamoto, C. M. and Shaw, R. H., 1967: Apparent photosynthesis in field soybean communities. Agron. J., 59, 73-75.

Sameshima, R., 1995: Estimating the absorptivity of solar radiation in soybean canopies - for use in crop models -. J. Agric. Meteorol., 51, 3745.

Shibles, R. M. and Weber, C. R., 1966: Interception of solar radiation and dry matter production by various soybean planting patterns. Crop Sci., 6, 55-59.

Shiraiwa, T. and Hashikawa, U., 1993: Variation analysis of efficiency of intercepted radiation conversion in the accumulation of dry matter by soybean. Jpn. J. Crop Sci., 62, 1-8.

Sinclair, T. R. and de Wit, C. T., 1975: Photosynthate and nitrogen requirements for seed production by various crops. Science, 189, 565-567.

Sinclair, T. R., 1986: Water and nitrogen limitations in soybean grain production 1. Model development. Field Crops Res., 15, 125-141.

Sinclair, T. R. and Horie, T., 1989: Leaf Nitrogen, Photosynthesis, and crop radiation use efficiency: a review. Crop Sci., 29, 90-98.

Sinclair, T. R., Shiraiwa, T. and Hammer, G. L., 1992: Variation in crop radiation-use efficiency with increased diffuse radiation. Crop Sci., 32, 1281-1284.

Wells, R., 1991: Soybean growth response to plant density: relationships among canopy photosynthesis, leaf area, and light interception. Crop Sci., 31, 755-760. 


\title{
ダイズ群落による乾物生産速度の解析およびモデリング 一日射強度への曲線的な反応一
}

\author{
鮫 島 良 次
}

（国際農林水産業研究センター）

\section{要 約}

作物群落による吸収日射量と乾物生産量に比例関係が 存在することは既往の多くの測定結果から明らかであり， その比例係数は日射利用効率 (RUE) と称されている。 $R U E$ を用いた生育解析・予測は多く行われているが, 通常 $R U E$ は日射強度依存性が無く, 日射強度 (タイムス ケールが一日である場合は日日射量, $R_{S}$ で代表される) 之乾物生産速度 $(D M P R)$ は比例すると仮定されている。 しかし, 遮光処理を行うと $R U E$ が増大する事, 群落光 合成速度が日射強度に対して双曲線型の反応を見せる事 は既知であり，乙れらは上の仮定に疑問を生じさせる。 そこで, 次の形のモデルを仮定して, DMPR とRUEの 日射強度依存性を解析した(ダイズ品種エンレイを供試)。

$$
D M P R=D M P R_{\max }\left(R_{S}\right) * g(\alpha)
$$

乙てで, $D M P R_{\text {max }}\left(R_{S}\right)$ は完全に日射を吸収する仮想
的な群落 (日射吸収率 $=1.0$ )の $D M P R, g(\alpha)$ は $D M P R$ に及ぼす $\alpha$ の影響。既往の文献に見られる結果を参考に, $D M P R_{\max }\left(R_{S}\right)$ には双曲線, $g(\alpha)$ には直線を採用し た。

遮光試験を含む固場試験データからモデルのパラメー 夕を決定した。生育初期とその後の期間で異なるパラメ 一夕を使用する必要があった。 $D M P R_{\max }\left(R_{S}\right)$ と $R_{S}$ の 明らかな曲線関係が認められた。RUEの $R_{S}$ 依存性を考 慮しない従来のモデルでは, 連続する低照度下で生育す るダイズの生育を再現することが出来ないが，乙のモデ ルを使用すれば可能であり, 本モデルは塞日照障害解析

・予測への応用が可能である。

キーワード : RUE, CGR, 生長解析, 群落光合成, Glycine $\max (\mathrm{L}$.$) Merr.$ 